\title{
STUDI TENTANG PENGETAHUAN GIZI IBU DAN KEBIASAAN MAKAN PADA RUMAH TANGGA DI DAERAH DATARAN TINGGI DAN PANTAI
}

\author{
(Mother's Nutrition Knowledge and Food Habits of Households in Highland and Coastal Areas)
}

Ali Khomsan ${ }^{1}$, Faisal Anwar ${ }^{1}$, Dadang Sukandar ${ }^{1}$, Hadi Riyadi ${ }^{1}$, Eddy S Mudjajanto ${ }^{1}$

\begin{abstract}
ABST RACT
Eating habits refer to the behavior of a person or a group of people in satisfying the need for food, which involves attitude, beliefs, and choice of food. To understand eating habits, what ought to be considered are food consumption (quantity and quality), preference of certain food, beliefs, taboo, and attitude toward certain foods. This research aims to assess mother's nutrition knowledge and food habits of the households. The study was conducted in a highland area of Bogor Regency and a coastal area of Indramayu Regency, West Java, Indonesia. In Bogor, 375 samples and in Indramayu 376 samples were selected randomly, so the total samples are 751. The data was collected through questionnaires. Mother's nutrition knowledge is better in Indramayu than in Bogor. The eating frequency of 1-2 times daily is still dominant in the households of both locations of research. A food priority for the members (under five year old children) of households who are prone to nutritional problems is important to reduce the risk of malnutrition. The consumption of food from animal sources (meat and eggs) in both regions of research is generally still low, i.e. less than a piece of meat/ week, and less than 1 egg/ week, except for the consumption of fish in Indramayu, which is relatively high. The vegetable consumption in Bogor is relatively high, but fruit consumption is lower than that in Indramayu.
\end{abstract}

Keywords: nutritional knowledge, food habits, household

\section{PENDAHULUAN}

\section{Latar Belakang}

Kebiasaan makan adalah tingkah laku manusia atau kelompok manusia dalam memenuhi kebutuhannya akan makan yang meliputi sikap, kepercayaan dan pemilihan makanan (Khumaidi, 1989). Suhardjo (1989) menyatakan bahwa kebiasaan makan individu atau kelompok individu adalah memilih pangan dan mengonsumsinya sebagai reaksi terhadap pengaruh fisiologis, psikologis, sosial dan budaya.

Tiga faktor terpenting yang mempengaruhi kebiasaan makan adalah ketersediaan pangan, pola sosial budaya dan faktor-faktor pribadi (Harper et al., 1986). Hal yang perlu diperhatikan dalam mempelajari kebiasaan makan adalah konsumsi pangan (kuantitas dan kualitas), kesukaan terhadap makanan tertentu, kepercayaan, pantangan, atau sikap terhadap makanan tertentu (Wahyuni, 1988).

Khumaidi (1989) menyatakan bahwa dari segi gizi, kebiasaan makan ada yang baik atau dapat menunjang terpenuhinya kecukupan gizi dan ada yang buruk (dapat menghambat terpe-

\footnotetext{
${ }^{1}$ Staf pengajar Departemen Gizi Masyarakat, Fakultas Ekologi Manusia (FEMA), IPB.
}

nuhinya kecukupan gizi), seperti adanya pantangan atau tabu yang berlawanan dengan konsep-konsep gizi. Menurut Williams (1993), masalah yang menyebabkan malnutrisi adalah tidak cukupnya pengetahuan gizi dan kurangnya pengertian tentang kebiasaan makan yang baik. Kebiasaan makan dalam rumahtangga penting untuk diperhatikan, karena kebiasaan makan mempengaruhi pemilihan dan penggunaan pangan dan selanjutnya mempengaruhi tinggi rendahnya mutu makanan rumahtangga.

Kebiasaan makan yang terbentuk sejak kecil dapat dipengaruhi oleh berbagai hal antara lain perbedaan etnis, tingkat sosial ekonomi, geografi, iklim, agama dan kepercayaan serta tingkat kemajuan teknologi (Wardiatmo, 1989). Kebiasaan makan banyak dipengaruhi oleh variabel lingkungan. Pilihan dan kegunaan makanan yang ada adalah merupakan komponen ekologi. Studi tentang konsumsi pangan di daerah pedesaan menunjukkan adanya keterkaitan antara tingkat konsumsi masyarakat dengan zona ekologi (Annegers, 1973 dalam den Hartog, 1995).

Menurut den Hartog (1995) kebiasaan makan dapat dibentuk oleh lingkungan sekitar dimana seseorang hidup. Adapun beberapa variabel lingkungan yang berpengaruh terhadap kebiasaan makan suatu masyarakat adalah lingkungan hidup yang meliputi topografi, 
keadaan tanah, iklim, dan flora, lingkungan budaya (sistem produksi pertanian) dan populasi (kelahiran, kematian, migrasi, pertambahan penduduk, umur dan jenis kelamin). Hal ini menjadi salah satu pemikiran mendasar untuk mengangkat penelitian ini.

\section{$\underline{\text { Tujuan }}$}

1. Mengetahui tingkat pengetahuan gizi ibu rumahtangga miskin dan tidak miskin di daerah dataran tinggi (Bogor) dan pantai (Indramayu).

2. Mengetahui kebiasaan makan rumahtangga yang meliputi frekuensi konsumsi pangan, prioritas makanan dan tabu makanan.

\section{METODE PENELITIAN}

\section{Desain, Tempat dan Waktu Penelitian}

Penelitian ini menggunakan desain crosssectional survey. Penelitian dilakukan di dua daerah yaitu Bogor (dataran tinggi) dan Indramayu (pantai). Masing-masing daerah diwakili oleh tiga kecamatan. Lokasi penelitian di daerah Bogor meliputi Kecamatan Ciomas, Dramaga dan Ciampea, sedangkan di daerah Indramayu meliputi Kecamatan Losarang, Kandanghaur, dan Sukra. Penelitian dilakukan selama 12 bulan yang dimulai pada November 2004 dan berakhir pada November 2005.

\section{Prosedur Penarikan Contoh}

Sampel keseluruhan berjumlah 751 rumahtangga dengan kriteria utama yaitu memiliki sekurang-kurangnya 1 (satu) anak balita dan memenuhi kriteria miskin atau tidak miskin menurut BKKBN. Jumlah rumahtangga miskin sebanyak 513 dan tidak miskin 238. Penarikan contoh dilakukan dengan menggunakan penarikan contoh acak pada kedua lokasi penelitian.

\section{Pengolahan dan Analisis Data}

Data yang dikumpulkan dalam penelitian ini adalah data pengetahuan gizi, frekuensi konsumsi pangan, prioritas makan, dan tabu makanan. Pengolahan data dilakukan dengan menggunakan program Microsoft Excel, SPSS, dan SAS. Pendugaan parameter yang bersifat umum meliputi pendugaan nilai rata-rata simpangan baku (standar deviasi) bagi semua peubah kontinu, dan proporsi bagi peubah kategorikal atau peubah kontinu yang dikategorikan.

\section{HASIL DAN PEMBAHASAN}

\section{Pengetahuan Gizi Ibu}

Tabel 1 menunjukkan nilai rata-rata pengetahuan gizi ibu di Bogor dan Indramayu. Nilai maksimum adalah 10 dan nilai minimum adalah 0. Sebaran nilai menunjukkan bahwa ibu dari rumahtangga miskin di Bogor memiliki nilai pengetahuan gizi 7.0. Nilai ini sedikit lebih tinggi daripada nilai ibu dari rumahtangga tidak miskin yaitu 6.8. Total keseluruhan (miskin dan tidak miskin) nilai rata-rata pengetahuan gizi ibu di Indramayu lebih tinggi (7.4) dibandingkan dengan ibu di Bogor (6.9).

Ibu memiliki peran besar dalam keluarga. Ibu-ibu di Indonesia bertanggungjawab dalam belanja pangan, mengatur menu keluarga, mendistribusikan makanan, dan berperan langsung dalam pemeliharaan anak. Pengetahuan gizi ibu akan sangat berpengaruh terhadap keadaan gizi keluarga (Suhardjo, 1989). Tingkat pengetahuan gizi ibu yang baik akan mempermudah pelaksanaan tanggung jawabnya dalam pemilihan jenis pangan yang mengandung gizi tinggi untuk seluruh keluarganya (Harper, Deaton, \& Driskel, 1986).

Tabel 1. Statistik Pengetahuan Gizi Ibu dalam Rumahtangga

\begin{tabular}{|c|c|c|c|c|}
\hline \multirow{2}{*}{$\begin{array}{c}\text { Tingkat } \\
\text { Kemiskinan }\end{array}$} & \multicolumn{2}{|c|}{ Bogor } & \multicolumn{2}{c|}{ Indramayu } \\
\cline { 2 - 5 } & $\begin{array}{c}\text { Rata- } \\
\text { rata }\end{array}$ & SD & $\begin{array}{c}\text { Rata- } \\
\text { rata }\end{array}$ & SD \\
\hline Miskin & 7.0 & 1.9 & 7.5 & 2.3 \\
\hline Tidak Miskin & 6.8 & 1.9 & 7.1 & 8 \\
\hline Miskin+Tidak Miskin & 6.9 & 1.9 & 7.4 & 2.2 \\
\hline
\end{tabular}

\section{Frekuensi Konsumsi Pangan}

\section{Frekuensi Makan Rumahtangga}

Frekuensi makan akan menentukan jumlah makanan yang masuk ke dalam tubuh seseorang sehingga akan menentukan tingkat kecukupan gizi. Tabel 2 menunjukkan bahwa frekuensi makan rumahtangga di Bogor sebagian besar adalah 1-2x perhari (60.0\%) dan untuk Indramayu (51.1\%) adalah $\geq 3 x$ per hari.

Sebagian besar rumahtangga di Bogor memiliki kebiasaan makan 1-2x sehari, namun bukan berarti kecukupan gizinya tidak terpenuhi, karena menurut Suhardjo, Hardinsyah dan Riyadi (1988), terdapat beberapa daerah di Indonesia yang memiliki kebiasaan makan dua kali sehari. Responden di Indramayu memiliki kebiasan makan tiga kali sehari atau lebih. 


\section{Pangan Pokok}

Beras masih menjadi makanan pokok sebagian besar masyarakat di Indonesia, termasuk di Bogor dan Indramayu. Tabel 3 menunjukkan bahwa sebagian besar rumah tangga miskin dan tidak miskin di Bogor dan Indramayu, mengonsumsi beras sebagai makanan pokok, yaitu antara 16-17 kali per minggu. Hal ini menunjukkan bahwa dalam satu hari rata-rata rumahtangga mengonsumsi beras sebanyak dua kali.

Tabel 2. Sebaran Rumahtangga menurut Frekuensi Makan

\begin{tabular}{|c|c|c|c|c|}
\hline \multirow{2}{*}{$\begin{array}{c}\text { Frekuensi Makan } \\
\text { (kali) }\end{array}$} & \multicolumn{2}{|c|}{ Bogor } & \multicolumn{2}{c|}{ Indramayu } \\
\cline { 2 - 5 } Miskin & $\mathbf{n}$ & $\%$ & $\mathbf{n}$ & $\%$ \\
\hline $1-2$ & & & & \\
\hline$\geq 3$ & 152 & 61.3 & 132 & 49.8 \\
\hline Total & 96 & 38.7 & 133 & 50.2 \\
\hline Tidak Miskin & 248 & 100 & 265 & 100 \\
\hline $1-2$ & & & & \\
\hline$\geq 3$ & 73 & 57.5 & 52 & 46.8 \\
\hline Total & 54 & 42.5 & 59 & 53.2 \\
\hline Miskin+Tidak Miskin & 127 & 100 & 111 & 100 \\
\hline $1-2$ & 225 & 60 & 184 & 48.9 \\
\hline$\geq 3$ & 150 & 40 & 192 & 51.1 \\
\hline Total & 375 & 100 & 376 & 100 \\
\hline
\end{tabular}

Tabel 3. Rata-rata Frekuensi Konsumsi Pangan Pokok pada Tingkat Rumahtangga (kali per minggu)

\begin{tabular}{|c|c|c|}
\hline J enis Pangan & Bogor & Indramayu \\
\hline Miskin & & \\
\hline Beras & 16.9 & 17.6 \\
\hline Jagung & 1.4 & 0.8 \\
\hline Singkong & 1.9 & 1.9 \\
\hline Ubi Jalar & 1.3 & 1.2 \\
\hline Tidak Miskin & & \\
\hline Beras & 16.8 & 17.6 \\
\hline Jagung & 1.5 & 0.9 \\
\hline Singkong & 1.4 & 1.6 \\
\hline Ubi Jalar & 1.3 & 0.9 \\
\hline
\end{tabular}

\section{Lauk-pauk}

Lauk-pauk yang biasa dikonsumsi oleh masyarakat di lokasi penelitian adalah : tahu, tempe, ikan, dan telur. Sementara itu, daging sangat jarang dikonsumsi karena harganya relatif mahal.
Konsumsi tahu dan tempe antara rumahtangga miskin dan tidak miskin di Bogor maupun Indramayu sebenarnya hampir sama. Rumahtangga miskin di Bogor mengonsumsi tahu (4.1 kali per minggu) dan tempe (4.3 kali per minggu), sedangkan frekuensi konsumsi di Indramayu adalah tahu (4.0 kali) dan tempe (4.2 kali). Untuk kelompok tidak miskin, frekuensi konsumsi tahu dan tempe di Bogor adalah masing-masing 4.5 kali dan 4.8 kali, sedangkan di Indramayu 3.6 kali dan 4.0 kali.

Tabel 4. Rata-rata Frekuensi Konsumsi Pangan Lauk-pauk pada Tingkat Rumahtangga (kali per minggu)

\begin{tabular}{|c|c|c|}
\hline Jenis Pangan & Bogor & Indramayu \\
\hline Miskin & & \\
\hline Tahu & 4.1 & 4.0 \\
\hline Tempe & 4.3 & 4.2 \\
\hline Ikan Asin & 7.1 & 2.2 \\
\hline Ikan Laut & 0.5 & 4.7 \\
\hline Ikan Tawar & 0.5 & 1.2 \\
\hline Ikan Pindang & 1.7 & 1.7 \\
\hline Telur & 3.6 & 4.2 \\
\hline Tidak Miskin & & \\
\hline Tahu & 4.5 & 3.6 \\
\hline Tempe & 4.8 & 4.0 \\
\hline Ikan Asin & 6.2 & 1.8 \\
\hline Ikan Laut & 1.1 & 4.9 \\
\hline Ikan Tawar & 0.8 & 1.5 \\
\hline Ikan Pindang & 1.7 & 1.6 \\
\hline Telur & 3.6 & 4.9 \\
\hline
\end{tabular}

\section{Sayur-sayuran}

Untuk rumahtangga miskin maupun tidak miskin, terdapat variasi frekuensi konsumsi sayur-sayuran antara responden di Bogor dan Indramayu. Rumahtangga di Bogor tampak memiliki frekuensi konsumsi lebih tinggi untuk semua jenis sayuran kecuali kacang panjang. Bogor sebagai wilayah dataran tinggi menghasilkan sayuran lebih banyak dibandingkan Indramayu sebagai wilayah pantai. Dengan frekuensi konsumsi sayuran seperti terlihat pada Tabel 5 dapat dikatakan bahwa setiap hari, rumahtangga di lokasi penelitian mengonsumsi sayuran secara berganti-ganti.

Buah

Tabel 6 menunjukkan bahwa di Bogor dan Indramayu, baik rumahtangga miskin maupun tidak miskin mengonsumsi buah dengan frekuensi yang hampir sama yaitu umumnya kurang dari satu kali per minggu. Untuk pisang, baik di Bogor dan Indramayu frekuensi konsumsinya relatif lebih tinggi dari- 
pada konsumsi buah yang lain yaitu lebih dari satu kali per minggu.

\section{Prioritas Pendistribusian Makanan}

Tabel 7 merupakan tabel yang memaparkan sebaran rumahtangga menurut individu yang diprioritaskan makannya. Penelitian ini mengungkapkan bahwa terdapat kecenderungan untuk memprioritaskan suami daripada anggota rumahtangga lainnya. Suami biasanya dianggap yang paling berkuasa dan kepadanya diberikan keistimewaan dalam banyak hal, termasuk hak khusus untuk mendapat bagian makanan yang paling baik dan paling banyak.

Dalam hal ini isteri akan cenderung untuk lebih mengutamakan anggota rumahtangga lainnya, misalnya suami atau anak. Jika istri harus memprioritaskan diri, hal tersebut terjadi karena keadaan fisiologis yang mereka alami, misalnya hamil atau menyusui.

Tabel 5. Rata-rata Frekuensi Konsumsi Pangan Sayur-sayuran pada Tingkat Rumahtangga (kali per minggu)

\begin{tabular}{|c|c|c|}
\hline J enis Pangan & Bogor & Indramayu \\
\hline Miskin & & \\
\hline Tomat & 8.1 & 6.9 \\
\hline Mentimun & 2.1 & 2.5 \\
\hline Wortel & 1.8 & 1.2 \\
\hline Bayam & 2.5 & 1.7 \\
\hline Kangkung & 2.3 & 1.9 \\
\hline Daun Singkong & 1.8 & 0.6 \\
\hline Labu Siam & 1.8 & 1.2 \\
\hline Sawi & 1.7 & 1.2 \\
\hline Kacang Panjang & 1.5 & 4.1 \\
\hline Kacang Tanah & 2.0 & 1.7 \\
\hline Kacang Buncis & 1.7 & 0.8 \\
\hline Tidak Miskin & & \\
\hline Tomat & 8.6 & 6.9 \\
\hline Mentimun & 2.3 & 2.3 \\
\hline Wortel & 2.0 & 1.2 \\
\hline Bayam & 2.4 & 1.6 \\
\hline Kangkung & 2.3 & 1.9 \\
\hline Daun Singkong & 1.6 & 0.7 \\
\hline Labu Siam & 1.9 & 1.3 \\
\hline Sawi & 2.0 & 1.1 \\
\hline Kacang Panjang & 2.3 & 3.2 \\
\hline Kacang Tanah & 1.7 & 1.9 \\
\hline Kacang Buncis & 2.0 & 1.0 \\
\hline
\end{tabular}

Kecenderungan untuk memberikan prioritas makanan yang utama kepada balita dalam penelitian ini masih sangat rendah, yaitu secara umum hanya $9.9 \%$ rumahtangga di Bogor yang memberikan prioritas utama kepada balita, dan tidak ada satupun di Indramayu. Menurut Sediaoetama (1991) anak-anak, terutama balita harus diberikan jatah utama dalam distribusi makanan rumahtangga karena anakanak sedang dalam proses pertumbuhan yang sangat pesat sehingga memerlukan zat-zat makanan yang relatif lebih banyak dengan kualitas yang lebih baik.

Tabel 6. Rata-rata Frekuensi Konsumsi Pangan Buah-buahan pada Tingkat Rumahtangga (kali per minggu)

\begin{tabular}{|c|c|c|}
\hline Jenis Pangan & Bogor & Indramayu \\
\hline Miskin & & \\
\hline Pepaya & 1.0 & 0.3 \\
\hline Pisang & 1.5 & 1.5 \\
\hline Mangga & 0.5 & 0.1 \\
\hline Rambutan & 0.7 & 0.4 \\
\hline Nanas & 0.1 & 0.2 \\
\hline Jambu & 0.8 & 0.4 \\
\hline Nangka & 0.2 & 0.1 \\
\hline Tidak Miskin & & \\
\hline Pepaya & 1.1 & 0.4 \\
\hline Pisang & 1.2 & 1.8 \\
\hline Mangga & 0.4 & 0.2 \\
\hline Rambutan & 0.4 & 0.3 \\
\hline Nanas & 0.1 & 0.3 \\
\hline Jambu & 1.0 & 0.4 \\
\hline Nangka & 0.3 & 0.2 \\
\hline
\end{tabular}

Tabel 7. Sebaran Rumahtangga menurut Prioritas dalam Pendistribusian Makan

\begin{tabular}{|l|c|c|c|c|}
\hline \multirow{2}{*}{$\begin{array}{c}\text { Anggota } \\
\text { Rumahtangga yang } \\
\text { Diprioritaskan }\end{array}$} & \multicolumn{2}{|c|}{ Bogor } & \multicolumn{2}{c|}{ Indramayu } \\
\cline { 3 - 5 } Miskin & & & & \\
\hline Suami & 129 & 81.1 & 124 & 98.4 \\
\hline Istri & 9 & 5.7 & 2 & 1.6 \\
\hline Balita dan lainnya & 21 & 13.2 & 0 & 0 \\
\hline Total & 159 & 100 & 126 & 100 \\
\hline Tidak Miskin & & & & \\
\hline Suami & 79 & 79.8 & 59 & 100 \\
\hline Istri & 5 & 5.1 & 0 & 0 \\
\hline Balita dan lainnya & 15 & 15.2 & 0 & 0 \\
\hline Total & 99 & 100 & 59 & 100 \\
\hline Miskin+Tidak Miskin & & & & \\
\hline Suami & 208 & 55.5 & 183 & 98.9 \\
\hline Istri & 14 & 3.7 & 2 & 1.1 \\
\hline Balita dan lainnya & 37 & 9.9 & 0 & 0 \\
\hline Total & 259 & 69.1 & 185 & 100 \\
\hline
\end{tabular}




\section{Tabu Makanan}

Tabu makanan masih dijumpai di lokasi penelitian. Tabu makanan bahkan sudah dijumpai sejak usia bayi/balita. Hal ini mengindikasikan masih rendahnya pemahaman gizi masyarakat dan oleh sebab itu perlu berbagai upaya untuk memperbaikinya. Pantangan atau tabu adalah suatu larangan untuk mengonsumsi suatu jenis makanan tertentu karena terdapat ancaman bahaya atau hukuman terhadap yang melanggarnya. Dalam ancaman bahaya ini terdapat kesan magis yaitu adanya kekuatan supernatural yang berbau mistik yang akan menghukum orang-orang yang melanggar pantangan atau tabu tersebut (Susanto, 1991).

Bayi, Balita Perempuan, dan Balita Laki-Laki. Di Bogor, meskipun sangat sedikit namun masih ada yang percaya bahwa kepada bayi dan balita laki-laki tidak boleh diberikan pisang ambon karena bisa menyebabkan alat kelamin/skrotumnya bengkak. Balita perempuan tidak boleh makan pantat ayam karena nanti ketika mereka sudah menikah bisa diduakan suami.

Sementara di Indramayu, makanan gurih yang diberikan kepada bayi dianggap membuat pertumbuhannya menjadi terhambat. Untuk balita perempuan, mereka dilarang untuk makan nanas dan timun. Selain itu balita perempuan dan laki-laki juga tidak boleh mengonsumsi ketan karena bisa menyebabkan anak menjadi cadel. Mereka menganggap bahwa tekstur ketan yang lengket menyebabkan anak tidak bisa menyebutkan aksara ' $r$ ' dengan benar.

Wanita dan Laki-laki Dewasa. Jenis makanan pantangan bagi wanita dan laki-laki dewasa lebih banyak karena alasan yang menyangkut dengan organ reproduksi/hubungan seksual suami istri. Hal ini berlaku pada sebagian besar responden di Bogor dan Indramayu. Makanan tersebut kebanyakan adalah sayur dan buah yang banyak mengandung air, misalnya nanas, pepaya, semangka, timun, dan labu siam. Jenis makanan tersebut dianggap bisa menyebabkan keputihan yang akhirnya dapat mengganggu keharmonisan hubungan suami dan istri. Sementara untuk laki-laki dewasa, baik di Bogor dan Indramayu memiliki suatu kepercayaan bahwa laki-laki dewasa dilarang makan terung, karena membuat mereka lemas dan mudah lelah.

Wanita Hamil. Di Bogor, jenis makanan yang sebagian besar dipantang oleh wanita hamil adalah nanas. Mengonsumsi nanas ketika usia kehamilan masih muda dianggap akan menggugurkan janin yang ada di rahim, dan meskipun bayi tersebut selamat sampai dilahirkan, namun proses kelahirannya akan sulit dan kulit bayi akan bersisik. Jenis makanan yang banyak dipantang wanita hamil di Indramayu adalah kerak nasi. Makanan ini dianggap sebagai penyebab sulitnya proses melahirkan karena anak akan menempel di rahim. Beberapa jenis ikan yaitu udang dan sotong juga dianggap sebagai penyebab bayi lahir sungsang, yaitu posisi bayi yang siap dilahirkan menjadi terbalik dari seharusnya, yaitu posisi kaki di bawah.

Wanita menyusui. Makanan pantangan wanita menyusui antara lain adalah ikan. Mereka beranggapan bahwa bau amis ikan akan menyebabkan ASI menjadi amis, sehingga bayi menjadi tidak mau menyusu. Hal ini berlaku untuk responden di Bogor dan Indramayu.

Orang Sakit. Ada beberapa jenis pangan yang dilarang untuk dikonsumsi orang yang menderita suatu penyakit tertentu. Misalnya makanan asin, tidak baik dikonsumsi oleh orang yang menderita penyakit darah tinggi, makanan sumber protein (ayam, telor, ikan) tidak boleh dikonsumsi oleh orang yang sakit kulit, kangkung tidak baik dikonsumsi oleh orang yang menderita rematik, asam urat dan sakit pinggang, dan lain-lain. Biasanya hal ini tidak berhubungan dengan kepercayaan atau tradisi tetapi berdasarkan petunjuk dokter atau pengalaman dari orang yang pernah mengalami penyakitnya.

\section{KESIMPULAN DAN SARAN}

\section{Kesimpulan}

Pengetahuan gizi ibu rumahtangga di Indramayu lebih baik daripada di Bogor. Namun demikian, rata-rata nilai pengetahuan gizi di kedua lokasi masih tergolong sedang sehingga masih diperlukan berbagai upaya (penyuluhan) untuk meningkatkannya.

Frekuensi makan 1-2 kali sehari masih cukup dominan pada rumahtangga di kedua lokasi penelitian. Di Bogor lebih banyak rumah tangga yang makan 1-2 kali sehari (60\%) dibandingkan di Indramayu (48.9\%).

Konsumsi pangan hewani (daging dan telur) di kedua lokasi penelitian umumnya masih rendah kecuali konsumsi ikan di Indramayu yang relatif tinggi. Hal ini karena akses ikan di Indramayu relatif lebih mudah daripada di Bogor.

Konsumsi sayur di Bogor relatif tinggi tetapi konsumsi buah-buahan lebih rendah dibandingkan di Indramayu. Bogor yang meru- 
pakan daerah pegunungan menghasilkan produk sayur lebih tinggi sehingga mudah diakses oleh masyarakatnya.

Prioritas makanan pada anggota rumah tangga yang rentan terhadap masalah gizi (anak balita) adalah penting untuk mengurangi risiko kurang gizi. Namun dalam penelitian ini, prioritas makanan justru ditujukan pada suami yang bukan termasuk golongan rawan. Di Bogor maupun Indramayu ditemukan fenomena yang sama dalam hal prioritas makanan pada suami.

Tabu makanan masih ditemukan di lokasi penelitian. Tabu makanan yang merupakan bagian dari budaya menganggap makananmakanan tertentu berbahaya karena alasanalasan yang tidak logis.

\section{Saran}

Penyuluhan gizi penting untuk terus menerus dilakukan di kedua lokasi penelitian untuk memperbaiki pengetahuan gizi dan kebiasaan makan masyarakat. Penyuluhan gizi menjadi landasan terjadinya perubahan pengetahuan, sikap dan keterampilan. Kelembagaan penyuluhan gizi seperti Posyandu perlu lebih diperkuat sehingga aktivitas penyuluhan tidak terabaikan.

\section{UCAPAN TERIMA KASIH}

Peneliti mengucapkan terima kasih dan apresiasi kepada Neys van Hoogstraten Foundation (NHF) The Netherlands, selaku penyandang dana penelitian sehingga penelitian ini dapat dilaksanakan.

\section{DAFTAR PUSTAKA}

den Hartog AP, WA van Staveren, \& ID Brouwer. 1995. Manual for Social Surveys on Food Habits and Consumption in Developing Countries. Margraf Verlag, Germany.

Harper LJ, BJ Deaton, \& JA Driskel. 1985. Pangan, Gizi, dan Pertanian (Suhardjo, penerjemah). UI Press, Jakarta.

Khumaidi M. 1989. Gizi Masyarakat. Departemen Pendidikan dan Kebudayaan, Direktorat Jenderal Pendidikan Tinggi dan Pusat Antar Universitas Pangan dan Gizi IPB, Bogor.

Sediaoetomo, AD. 1991. Ilmu Gizi. Dian Rakyat, Jakarta.

Suhardjo. 1989. Sosio Budaya Gizi. Departemen Pendidikan dan Kebudayaan, Direktorat Jenderal Pendidikan Tinggi, dan Pusat Antar Universitas Pangan dan Gizi IPB, Bogor.

Susanto D. 1991. Fungsi-fungsi sosio-budaya makanan. Majalah Pangan, 9, 51-56.

Wahyuni S. 1988. Konsumsi Ikan, Kebiasaan Makan Anak Balita, dan Status Gizi Anak Sekolah Keluarga Nelayan dan Bukan Nelayan di Kelurahan Tambak, Kecamatan Kenjeran, Kotamadya Surabaya, Jawa Timur. Skripsi Sarjana Jurusan Gizi Masyarakat dan Sumber daya Keluarga, Fakultas Pertanian, IPB, Bogor.

Wardiatmo T. 1989. Makanan dalam arti sehat dan sosial. Buletin Gizi, 2(13).

William SR. 1973. Nutrition and Diet Therapy. Moshby, St Louis. 